\title{
ARTYKUtY
}

Klio. Czasopismo poświęcone dziejom Polski i powszechnym

PL ISSN 1643-8191, t. 43 (4)/2017, s. 69-84

(c) (1) $\Theta$

http://dx.doi.org/10.12775/KLIO.2017.045

Danuta Raj, Jakub Węglorz

\section{Wódka wódce nierówna. Problematyka leczniczych ekstraktów ziołowych w epoce nowożytnej}

\section{Therapeutic herbal extracts in the early modern era Europe}

Streszczenie: Określenie „wódka” - występujące w nowożytnych źródłach opisujących stosowane leki - niesie ze sobą zasadniczą niejednoznaczność. W zależności od okresu i lokalnych zwyczajów termin ten mógł oznaczać wyciąg wodny, destylat wodny lub wodno-alkoholowy, bądź też nalewkę alkoholową. Autorzy źródeł, niestety, rzadko specyfikują, jakie konkretnie znaczenie słowa „wódka” mają na myśli, co pociąga za sobą szereg trudności interpretacyjnych. Niniejszy artykuł ma na celu wskazać przykłady stosowania zróżnicowanego nazewnictwa i występowania różnych odmian ekstraktów ziołowych w epoce nowożytnej. Autorzy wyszczególniają stosowane procedury produkcyjne i ich wpływ na przewidywaną skuteczność gotowego preparatu.

Dr Danuta Raj - Uniwersytet Medyczny im. Piastów Śląskich, Wydział Farmaceutyczny, Katedra i Zakład Farmakognozji, ul. Borowska 211a, 50-556 Wrocław, danuta.raj@ umed.wroc.pl; dr Jakub Węglorz - Uniwersytet Wrocławski, Instytut Historyczny, Zakład Historii Polski i Powszechnej XVI-XVIII wieku, ul. Szewska 49, 50-139 Wrocław, jakub. weglorz@uwr.edu.pl. 
Abstract: The Polish term "wódka" (vodka) appearing in modern sources describing the usage of drugs causes interpretational ambiguity. Depending on the period and local customs, this term could mean water extract, water distillate or water-alcoholic or alcohol tincture. Unfortunately, the authors of the historical sources rarely specify which meaning of the term "wódka" they actually meant. This leads to a number of interpretational difficulties. This article aims to show the consequences of usage of different nomenclature and the occurrence of varieties of herbal extracts in the modern era. Authors describe the production procedures used and their impact on the expected effectiveness of the final product.

Słowa kluczowe: historia medycyny; XVI w.; XVII w.; XVIII w.; ziołolecznictwo

Keywords: history of medicine; XVI century; XVII century; XVIII century; phytotherapy; herbalism

Alykuł ten poświęcony jest przedstawieniu sposobów wytwarzania trudności i niejednoznaczności interpretacyjnych na przewidywany efekt terapeutyczny analizowanych specyfików. W celu wskazania problemów i kontrowersji związanych z nieujednoliconym zapisem nowożytnych recept przebadano sposoby wykonywania wyciąów ziołowych występujące w staropolskich drukach medycznych i poradnikarskich z XVII i XVIII wieku oraz przeanalizowano nazewnictwo związane z produkcją ekstraktów ziołowych i możliwości jego interpretacji. Pomocniczo wykorzystano także szereg rękopisów medycznych, kalendarzy oraz pamiętników, diariuszy i zbiorów korespondencji z epoki ${ }^{52}$.

Medycyna oficjalna epoki nowożytnej w zasadniczym stopniu opierała się na założeniach patologii humoralnej. Doktryna ta dominowała w dyskursie o zdrowiu do końca XVIII wieku, a w niektórych aspektach

52 Całość bazy źródłowej dla prowadzonych badań stanowił zbiór prawie 40 źródeł pamiętnikarskich oraz korespondencyjnych, a także ponad 60 druków i rękopisów o tematyce medycznej pochodzących z terenów Rzeczypospolitej Obojga Narodów z okresu od końca XVI do końca XVIII wieku. Bazę źródłową szczegółowo scharakteryzowano w: J. Węglorz, Zdrowie, choroba i lecznictwo w spoteczeństwie Rzeczypospolitej XVI-XVIII wieku, Toruń 2015, s. 35-50. 
jej wpływy daje się zauważyć nawet w późniejszych stuleciach. Głosiła ona, że organizm człowieka składa się z czterech humorów (krew, flegma, żółć i czarna żółć), które nawiązywały do czterech żywiołów. Warunkiem zachowania zdrowia było przede wszystkim utrzymanie równowagi między krążącymi w ciele humorami oraz ewentualne korygowanie nieprawidłowości poprzez zastosowanie właściwych środków leczniczych ${ }^{53}$. Założenia $\mathrm{i}$ istota patologii humoralnej były już wielokrotnie opisywane w literaturze, ich przytaczanie nie jest zresztą w tym momencie niezbędne z punktu widzenia prowadzonych rozważań nad dawnymi ziołowymi ekstraktami leczniczymi. Dla przedstawianej problematyki kluczowe jest natomiast uwzględnienie specyfiki funkcjonowania dawnej medycyny. Przede wszystkim zaznaczyć należy, że nowożytna doktryna humoralna była konglomeratem wielu poglądów i naleciałości kumulowanych przez kilkanaście stuleci. Przyjmuje się, że została ukształtowana przez wpływ trzech wielkich starożytnych mistrzów: Hipokratesa, Arystotelesa i Galena. Swymi korzeniami sięgała jednak głębiej, odwołując się do rozważań Heraklita, Empedoklesa i Demokryta. Jednak nawet u swych podstaw, w epoce antyku, koncepcja humoralizmu nie miała jednolitej postaci i dzieliła się na wiele odłamów, nieraz znacząco różniących się sposobem postrzegania organizmu ludzkiego i metod jego leczenia ${ }^{54}$. Istotne zmiany do doktryny wprowadzano pod wpływem chrześcijaństwa i średniowiecznej scholastyki, a później także odkryć związanych z początkami chemii, fizyki, astronomii oraz filozofią oświecenia. Co jednak najważniejsze: w całym tym długim procesie przeobrażeń i adaptacji nie wytworzyła się spójna podstawa, której oparciem byłaby jednolita teoria i uporządkowana struktura wiedzy, nie ujednolicono też procedur badawczych czy leczniczych. Jako gałąź wiedzy medycyna często przybierała formę kazuistyki, obserwacji pojedynczych przypadków

53 Do najpopularniejszych metod mających usunąć z organizmu zepsute lub występujące w nadmiarze humory zaliczyć należy: prowokowanie przeczyszczeń i wymiotów, upuszczanie krwi, leki moczopędne i napotne, środki rozgrzewające lub ochładzające humory (zarówno w postaci gorących lub zimnych kąpieli czy okładów, jak i poprzez zastosowanie odpowiednich leków).

${ }^{54} \mathrm{O}$ medycynie epoki antyku zob.: W. Szumowski, Historia medycyny filozoficznie ujęta, Kęty 2008, s. 84-162. 
chorobowych ${ }^{55}$, które próbowano zrozumieć, jednak bez możliwości ustalenia powtarzalnych prawidłowości. Dopiero pod koniec omawianej epoki nauka medyczna zaczęła wdrażać pierwsze narzędzia umożliwiające przeprowadzanie obiektywnej i powtarzalnej oceny stanu zdrowia człowieka oraz precyzyjnej obserwacji prawidłowości w przebiegu choroby i weryfikowania realnych efektów stosowanych środków terapeutycznych ${ }^{56}$. Z czasem możliwości te poszerzyły się do tego stopnia, że w dzisiejszych czasach lekarz często bardziej ufa wynikom badań niż relacjom pacjenta. Niemniej jednak do końca XVIII wieku dominował sposób diagnozowania dolegliwości oparty na wywiadzie z pacjentem i jego otoczeniem oraz odwołaniu się do indywidualnej interpretacji serii parametró ${ }^{57}$ o raczej subiektywnym i jakościowym (niekwantytatywnym) charakterze. Interpretacja obserwacji także nastręczała trudności, nie znano bowiem pojęcia objawów charakterystycznych i przeważnie o rozpoznaniu konkretnej choroby decydować mogło występowanie szerokiego spektrum symptomów, które pojawiać się mogły również w przypadku innych dolegliwości lub mogły stanowić objaw wspólistniejący (np. gorączka, pocenie, mętny kolor moczu, podenerwowanie, bladość skóry, biegunka itp.). Co istotne, w wielu niejedno-

55 Wiele z nowożytnych prac medycznych mieściło w tytule słowa observationes lub curiosa, wskazując na jednostkowość opisywanej wiedzy i doświadczeń.

${ }^{56}$ Próby prowadzenia obserwacji i opisywania objawów według ujednoliconego schematu podejmował już w początkach XVIII w. Herman Boerhaave, a jednym z pierwszych narzędzi umożliwiających obiektywną obserwację powtarzalnych, kwantytatywnych parametrów był termometr rtęciowy i skala stopniowa opisana przez Daniela Gabriela Fahrenheita w 1724 roku.

57 Takich jak np. wygląd oraz zapach moczu i kału, zapach potu, wygląd oczu i skóry, siła i miarowość pracy serca (ale nie częstość tętna!), a we wcześniejszych wiekach też $\mathrm{m}$.in. położenie gwiazd i planet. O roli i specyfice diagnostyki w patologii humoralnej więcej w: Z. Kalemba, Wptyw koncepcji makro- i mikrokosmosu na pojmowanie choroby i cztowieka chorego, „Medycyna Nowożytna. Studia nad historią medycyny” (1998), t. 5, z. 1, s. 29-30; F. Lebrun, Jak dawniej leczono. Lekarze, świeci i czarodzieje w XVII i XVIII wieku, przet. Z. Podgórska-Klawe, Warszawa 1997, s. 59-62; M. Nicolson, The art of diagnosis: medicine and the five senses, [w:] Companion encyclopedia of the history of medicine, vol. 2, ed. by W.F. Bynum and R. Porter, London-New York 1993, s. 801-823; E. Shorter, The history of the doctor-patient relationship, [w:] Companion encyclopedia of the history of medicine, vol. 2, ed. by W.F. Bynum and R. Porter, London-New York 1993, s. 783-800; J. Węglorz, op. cit., s. 81-83. 
znacznych sytuacjach lekarz pozostawał zdany głównie na opis dolegliwości odczuwanych przez pacjenta, co niekoniecznie odzwierciedlało rzeczywisty stan organizmu. Wobec niemożności ustalenia kwantytatywnych parametrów opisujących człowieka i jego zdrowie przez kolejne stulecia królowała uznaniowość w ocenie skuteczności procesu leczenia związana z nieweryfikowalnością jego wyników. Brak obiektywnych metod oceny stanu zdrowia i efektów leczenia powodował, że pod wpływem kolejnych epok, odkryć i zmian sposobu postrzegania człowieka rozrastał się wachlarz interpretacji zasad funkcjonowania organizmu. Poszerzało się również spektrum stosowanych metod terapii, gdyż w niewielkim tylko stopniu odrzucano starsze koncepcje. Wielość równocennych, bo w takim samym stopniu nieweryfikowalnych metod i teorii występujących w ramach humoralizmu była w epoce nowożytnej stałym elementem wiedzy medycznej. Owocowało to mnogością możliwych interpretacji stanu zdrowia i zalecanych terapii, potęgowaną przez zatomizowanie środowiska lekarskiego. Opisywane nieraz w źródłach żywiołowe kłótnie odbywające się na konsyliach lekarskich uwidaczniają istotę problemu - bardzo często spór nie dotyczył jedynie doboru skuteczniejszego lekarstwa, ale wskazywał na fundamentalne rozbieżności w interpretacji samej istoty danej choroby ${ }^{58}$. Różnica zdań wynikała z odmiennego postrzegania objawów dolegliwości, a niemożliwość obiektywnego zweryfikowania diagnozy i skuteczności przedsięwziętej terapii powodowała, że tego rodzaju spory pozostawały nierozstrzygnięte (lub decydował większy autorytet jednego z oponentów). Wręcz oszałamiająca liczba recept medycznych i zaleceń terapeutycznych na każdą znaną wówczas dolegliwość zawartą $\mathrm{w}$ dyspensatoriach i poradnikach medycznych epoki nowożytnej wynika w dużym stopniu z niemożliwości zweryfikowania ich skuteczności oraz odsiania tych nieprzydatnych. Standaryzacja pro-

${ }^{58} \mathrm{O}$ rozdyskutowanych i zwalczających się lekarzach pisał m.in. Albrycht Stanisław Radziwiłł: „Krafft, inny lekarz królewski, wiedziony nienawiścią do tego pierwszego podał królowi przeciwne lekarstwo, tak że skoro król o tym dowiedział się w obawie, by wzajemne ich nienawiści nie zaszkodziły jego życiu, zwolnił Kraffta i obdarowawszy, odprawił”, „król znów zapadł ciężej na zdrowiu, a doktorzy medycyny nie mogli się między sobą zgodzić ani sposobem myślenia, ani co do diagnozy, owszem, wzajemnie się lżyli”: A. S. Radziwiłł, Pamiętnik o dziejach w Polsce. Tom 2: 1637-1646, tłum. i oprac. A. Przyboś i R. Żelewski, Warszawa 1980, s. 216, 290. 
cedur medycznych i składu leków nie była wówczas znana, co powodowało, że te same dolegliwości leczono odmiennymi specyfikami (w zależności od zapatrywań lekarza), które przygotowywano i stosowano na różne sposoby. Dotyczyło to oczywiście także ekstraktów ziołowych, w przypadku których dodatkową trudnością jest także niejednoznaczne nazewnictwo i nieprecyzyjnie określony sposób przygotowania preparatów, potęgujące jeszcze chaos na płaszczyźnie pojęciowej.

Poważnym problemem przy próbie identyfikacji leczniczych ekstraktów ziołowych jest wieloznaczne słownictwo używane do ich określania. Niemało trudności stwarza już samo słowo „wódka” (łac. aqua), którego w terminologii medycznej aż do wieku XVI używano na określenie wodnych destylatów roślinnych (lub wykonanych z innych substancji), zwanych też wodami aromatycznymi. Dopiero na przestrzeni XVII wieku dominujące stało się użycie słowa „wódka” w znaczeniu destylatu alkoholowego, niemniej jednak w tym okresie nadal można się natknąć na przykłady wykorzystania omawianego terminu w obydwu znaczeniach. Pod koniec XVII i w XVIII stuleciu pojęcie „wódka” stosowano już prawie zawsze w odniesieniu do alkoholu, choć oczywiście można znaleźć wyjątki od tej reguły. Ciekawą ilustracją przedstawianego fenomenu jest relacja Bazylego Rudomicza. W 1667 roku opisał on swój sen, w którym znajoma kobieta podeszła do niego: „dała wody trocha na oblanie onej i przywiodszy mię ad mansionem [do mieszkania - red.] wpuściała [wpuściła -red.], którą trocha pokropiłem oną wódką i ona mię vicissim [nawzajem - red.]"59. Autor, opisując sytuację, używa na określenie tej samej substancji raz słowa woda, a raz wódka. Łącznie z przedstawionym kontekstem (pokropienie) sugeruje to, że mamy do czynienia z wodą aromatyczną, jednak wymienne użycie zarówno słowa „woda”, jak i „wódka” jest symptomatyczne. O ile więc destylaty alkoholowe praktycznie zawsze nazywano wódką lub gorzałką, nigdy zaś „wodą”, to zdarzało się, że na określenie wodnych destylatów stosowano słowo „wódka”. W przypadku leczniczych „gorzałek” występują pewne dodatkowe teoretyczne wątpliwości, gdyż przepisy na ich wyko-

59 B. Rudomicz, Efemeros, czyli Diariusz prywatny pisany w Zamościu w latach 1656-1672. Część druga 1664-1672, tłum. W. Froch, oprac. M. L. Klementowski i W. Froch, Lublin 2002, s. 143. 
nanie często zakładają użycie jako surowca „wódki”, nie specyfikując przy tym, czy chodzi o destylat wodny czy alkoholowy. Wydaje się jednak, że w tej konkretnej sytuacji chodziło zawsze o destylat alkoholowy, gdyż występujący kontekst i powszechne wykorzystanie słowa "gorzałka” w epoce staropolskiej w znaczeniu napoju alkoholowego pozwalają na przyjęcie takiego założenia.

Wódki lecznicze stosowane były w Europie od średniowiecza, a w epoce nowożytnej cieszyły się bardzo dużą popularnością. Trudno jest jednoznacznie określić, jaka część z pojawiających się preparatów nazywanych wódkami była w istocie ekstraktami wodno-alkoholowymi. Wydaje się jednak, że nawet przy założeniu, że część z nich bazowała na ekstraktach wodnych, spożycie etanolu w postaci wódek i gorzałek leczniczych było znaczne. Oczywiście w epoce staropolskiej zdawano sobie sprawę ze szkodliwości spożywania alkoholu, ale nie wiązano jej z „wódkami” w ogólności, a raczej z częstym i intensywnym piciem (na umór). Po śmiertelnej chorobie swego brata Samuel Maskiewicz zanotował: „być może, iż zepsuł swoje zdrowie gorzałką"60. Swój pogląd uzasadniał przytaczając relację z pijatyki, która skończyła się zamroczeniem wszystkich uczestników oprócz dwójki - Niedźwieckiego i Maskiewicza, którzy kontynuowali pijatykę: „pili oni obadwa do tyla, iż tamten padł martwym, wynieśli go i mieli o nim staranie całą noc, co chwila oczekując śmierci, i dusza w nim ledwie się trzymała. [...] Niedzwiecki wyzionął ducha. Brat [Samuela Maskiewicza J.W.] go pochował, i był zdrowym, ale taka straszna poczestka nie mogła mu nieszkodzic" "61. Szkodliwe skutki długotrwałej ekspozycji na działanie alkoholu dostrzegano w przypadku kobiet. Jędrzej Kitowicz twierdził, że: „wódeczką mdlącą poleweczkę zakrapiając, po trosze się gorzałką rozpajały i na rozmaite jędze, dziwaczki, chimeryczki, nareszcie na pijaczki ogniste wychodziły"62. W tym kontekście zbawienna miała być kawa, gdyż dawała alternatywę dla spożywanego po obiedzie alkoholu: „było to albowiem na

60 S. Maskiewicz, Pamiętniki Samuela Maskiewicza: początek swój biorą od roku 1594 w lata pod sobie idace, oprac. J. Zakrzewski, Wilno 1838, s. 78.

${ }^{61}$ Ibidem, s. 79.

${ }^{62}$ J. Kitowicz, Opis obyczajów za panowania Augusta III, oprac. R. Pollak, Wrocław 2003, s. 492. 
kształt przywileju zdrowia, że kto pił kawę, nie mógł być oprymowany winem" ${ }^{63}$.

Wśród wszystkich leków stosowanych w medycynie staropolskiej wódki występowały szczególnie często, stanowiąc remedia na wiele różnych chorób. Według dawnych poglądów odpowiednio dobrana lecznicza wódka „do sił i zdrowia przyprowadza” ${ }^{64}$, może też być pomocna na dolegliwości żołądkowe, gdyż: „likwory francuskie są jak nasze wódki gdańskie z wina pędzone, dla żołądka są rezolucją" "5. Jan Antoni Chrapowicki w celu wyleczenia kamieni moczowych posyłał Elżbiecie z Podchocimskich Zenowiczowej „wódki brzozowej na kamienie” ${ }^{66}$, a konieczność stosowania trudno dostępnej na wojnie "gorzałki” jako remedium przeciw zatruciom pokarmowym wychwalał Mikołaj Dyakowski: „po dwa złote kwatyrkę płacić musieliśmy, gdyż była potrzebna na wojskową chorobę, to jest dyssenteryją" ${ }^{67}$. Lecznicze wódki stosowano zarówno wewnętrznie, jak i zewnętrznie - gdy Jana III Sobieskiego: „nie wiedzieć skąd i jakiej okazyjej katar go ciężki opanował"68, królowa osobiście leczyła małżonka nacieraniem wódkami węgierskimi. Jadwiga Rafałowiczówna zanotowała zaś o doktorze „rodem z Gdańska”, który „leczy na oczy dwie białogłowy, wódką jakąś napuszczając im i wyprowadza wszelką do ciemnoty wilgoć” ${ }^{69}$. Jedną z ważniejszych, niemal cudownych właściwości przypisywanych wódkom była moc otrzeźwiania po utracie przytomności, czy wręcz przywracania do życia w sytuacjach jego ekstremalnego zagrożenia. Wobec nagłej i gwałtownej choroby wojewody mazowieckiego Franciszka Wessela królewicz Jakub So-

${ }^{63}$ Ibidem, s. 490.

${ }^{64}$ K. Opaliński, Listy Krzysztofa Opalińskiego do brata Eukasza 1641-1653, red. R. Pollak, Wrocław 1957, s. 319.

65 J. Charkiewicz, Dyjariusz podróży hiszpańskiej z Wilna do miasta Walencyi, oprac. B. Rok, Wrocław 1998, s. 83.

${ }^{66}$ J. A. Chrapowicki, Diariusz. Czesść pierwsza: lata 1656-1664, Warszawa 1978, s. 390.

${ }^{67}$ M. Dyakowski, Dyaryusz wiedeńskiej okazyji, do druku przygotowali, wstępem i przypisami opatrzyli J. A. Kosiński, J. Długosz, Warszawa 1983, s. 88.

${ }^{68}$ K. Sarnecki, Pamiętniki z czasów Jana Sobieskiego, oprac. J. Woliński, Wrocław 2004, s. 147.

69 J. Rafałowiczówna, A z Warszawy nowiny te... . Listy do Elżbiety Sieniawskiej z lat 1710-1720, oprac. B. Popiołek, Kraków 2000, s. 227. 
bieski próbował go osobiście ratować: „różnymi wódkami rękę swoją, gdy go już śmiertelnego nawiedzał, nacierał, aby go ożywić, ale i te nie pomogły"70. Hetmana wielkiego litewskiego Lwa Sapiehę, którego w czasie uczty „nagle zmroczonego położono na krześle do noszenia"”1, także próbowano ratować: „pobudzano go najmocniejszymi wódkami, daremnie usiłowano wywołać lekki oddech”72. Gdy zaś król Zygmunt III Waza „został tknięty paraliżem” i miał „oko i część twarzy porażone”’3, w ramach leczenia „podtrzymywano jego siły lekarstwami, krzepiącymi wódkami, chcąc przezwyciężyć chorobę" ${ }^{74}$. Niestety po trzech dniach, pomimo iż „orzeźwiano go wódkami"75, król zmarł. Używano wódek także do cucenia nieprzytomnych, np. w przypadku królowej Marysieńki, która: „jedząc obiad z królem jm. u stołu zemdlała [...] i wódkami różnymi nacierać się kazała; ledwie godzinę do siebie przyszła”76. O osobliwej próbie ocucenia człowieka, który upadając uderzył głową w krawędź ławy, zanotował Jan Chryzostom Pasek: „pana Kordowskiego trzeźwić, wódki w nos lać”77. O dużej popularności wódek jako środka leczniczego świadczyć może także znaczna liczba przepisów na ich zastosowanie (a czasem też przygotowanie), zamieszczana w poradnikach medycznych i gospodarskich z omawianego okresu, które nieraz już w tytule chwaliły się posiadaniem rozdziału poświęconego temu zagadnieniu $^{78}$.

Kolejnym - oprócz identyfikacji nazwy - problemem, który napotyka badacz dawnych metod leczenia, jest trudność w ustaleniu składu i sposobu przygotowania wymienionego $\mathrm{w}$ źródłach preparatu. W ogromnej więk-

${ }^{70}$ K. Sarnecki, op. cit., s. 522.

71 A. S. Radziwiłł, Pamiętnik o dziejach w Polsce. Tom 1: 1632-1636, tłum. i oprac. A. Przyboś i R. Żelewski, Warszawa 1980, s. 315.

72 Ibidem.

73 Ibidem, s. 107.

${ }^{74}$ Ibidem, s. 109.

75 Ibidem, s. 110.

${ }^{76}$ K. Sarnecki, op. cit., s. 207.

77 J. Ch. Pasek, Pamiętniki, wstęp i objaśnienia W. Czapliński, Wrocław 2003, s. 441.

78 Wymienić tu można np. Lekarstwa domowe zebrane z rozmaitych autorów. [...] $Z$ rozszyrzeniem lekarstw, y przydatkiem o niektórych wódkach, na co sa pożyteczne. Ktemu też przydano sposób robienia pierniczków rozmaitych, Lubcza 1622. 
szości przypadków autorzy poprzestają na samym stwierdzeniu użycia leku (np. wódki) lub ewentualnie podaniu nazwy preparatu (np. wódka brzozowa). W dawnych egodokumentach dokładny skład medykamentów lub opis ich przyrządzenia występuje niezmiernie rzadko, co jest związane z charakterem tego rodzaju źródeł. Trudności potęguje jednak fakt, że poradniki medyczne i lekospisy bardzo często także nie specyfikują dokładnego składu i sposobu przygotowania leczniczych ekstraktów. Przeważnie ograniczają się jedynie do scharakteryzowania przypisywanych mu właściwości i określenia schorzeń, w których jest on pomocny. Tymczasem zarówno użyte surowce, jak i sposób ich obróbki ma fundamentalne znaczenie dla potencjalnej aktywności biologicznej finalnego preparatu. W medycynie nowożytnej da się wskazać cztery podstawowe sposoby uzyskiwania leczniczych ekstraktów: macerację, destylację, napar i odwar ${ }^{79}$. Maceracja to uzyskiwanie ekstraktu poprzez zalanie substancji roślinnej porcją rozpuszczalnika i pozostawienie na jakiś czas, po którym następuje zlanie lub odsączenie rozpuszczalnika. W ten sposób przygotowuje się dziś większość nalewek roślinnych, metoda ta była popularna także w produkcji leków w epoce staropolskiej. Destylacja (zwana też przepalaniem) to ogrzewanie w alembiku lub retorcie roztworu wodnego lub alkoholowo-wodnego i kondensacja (skraplanie) par w oddzielnym naczyniu (odbieralniku). W przypadku leczniczych wódek bardzo często destylowano uprzednio wykonane maceraty wodne lub wodno-alkoholowe. Napar uzyskuje się poprzez zalanie substancji roślinnej gorącą wodą i pozostawienie w naczyniu przez jakiś czas, często do ostygnięcia. Odwar zaś polega na zalaniu składników zimną lub ciepłą wodą, ogrzaniu do wrzenia i utrzymywaniu we wrzeniu przez pewien czas. Dwie ostatnie metody, choć były wykorzystywane w medycynie nowożytnej ${ }^{80}$, w produkcji wódek leczniczych praktycznie nie występowały.

79 Zob. Farmacja stosowana: podręcznik dla studentów farmacji, red. S. Janicki, A. Fiebig, M. Sznitowska, T. Achmatowicz, Warszawa 2003.

${ }^{80}$ Metodą naparu uzyskiwano m.in. kawę i herbatę, stosowane także leczniczo. Herbata do XVIII w. służyła głównie jako środek do płukania gardła, później jednak zauważono jej inne walory zdrowotne. Kawa z kolei rozpowszechniała się w Europie od końca XVII w. i w XVIII stuleciu stała się niezmiernie popularnym napojem, któremu przypisywano tak wiele zalet, że nabrał statusu niemal panaceum. Nawet prości chłopi w XVIII wieku dawali się ponieść modzie na kawę i przyrządzali sobie jej namiastkę z palo- 
Jak już wspomniano, sposób wykonania preparatu ma fundamentalne znaczenie dla jego składu chemicznego, a przez to wywieranego przezeń efektu. Niestety, bardzo często dawne poradniki, a nawet receptariusze, choć wyszczególniały nazwy odpowiednich na daną dolegliwość medykamentów, czasem też podawały skład leku, z rzadka specyfikowały metody jego wykonania. Bywało, że autorzy (jak np. Jakub Kazimierz Haur ${ }^{81}$ ) opisywali krok po kroku sposób przygotowania niektórych preparatów gospodarskich i leczniczych, ale w przypadku leczniczych wódek poprzestawali na wymienieniu ich z nazwy. Można by domniemywać, że wynikało to z faktu, iż sposób wykonania był ustalony i wszystkim dobrze znany, tak jednak nie było. W zależności od autora i epoki pojawiające się opisy przygotowania preparatów różnią się. Zdarza się nawet, że w tym samym receptariuszu znaleźć można odmienne przepisy na wykonanie specyfiku o takiej samej nazwie. Dla przykładu porównać można dwa przepisy na „wódkę cynamonową" z Compendium Medicum Auctum ${ }^{82}$. Różnią się one składem: pierwszy zawiera tylko cynamon i anyż, drugi - cynamon, skórki pomarańczowe i kardamon. Obydwa przepisy zakładają przedestylowanie substratów, przy czym drugi zaznacza, że powinno się to odbyć dopiero po całonocnym namaczaniu. Co istotne, odmienna jest też wykorzystana baza do wykonania ekstraktu - w pierwszym wypadku woda, a w drugim mieszanina wódki anyżowej i wina. Jak widać, w przypadku pierwszej recepty - w przeciwieństwie do drugiej ${ }^{83}$ - przedestylowany ekstrakt nie

nych i zmielonych żołędzi: Z. Kuchowicz, Cztowiek polskiego baroku, Łódź 1992, s. 61-62; F. Lebrun, Jak dawniej leczono, Warszawa 1997, s. 69; G. Vigarello, Historia zdrowia i choroby. Od średniowiecza do wspótczesności, Warszawa 1997, s. 115-118, 123.

${ }^{81}$ J. K. Haur, Oekonomika ziemiańska generalna Punktami Partykularnemi, Interrogatoryami Gospodarskiemi, Praktyka Miesięczna, Modellurzami albo Tabulami Arythmetycznemi obiaśniona przez Jakub Kazimierza Haura..., Warszawa 1744, s. 117-186.

${ }^{82}$ Compendium medicum auctum. To iest krótkie zebranie i opisanie chorób ich różności, przyczyn, znaków, sposobów do leczenia. Także różnych sposobów robienia Wodek, Oleykow, Julepów, Syropów, Konfitur, Maści, Plastrów, etc. i różnych osobliwych rzeczy..., Częstochowa 1789 , s. 593-594.

'bidem, s. 626-627.

${ }^{83}$ Wódka anyżowa użyta jako rozpuszczalnik do maceracji niekoniecznie musiała zawierać alkohol, o czym traktuje dalszy fragment tekstu. Niemniej jednak do maceratu dodano także wino, które już z pewnością alkohol zawierało. 
zawiera alkoholu, choć obydwie figurują pod nazwą „wódka cytrynowa”. W obydwu przypadkach przepis dopuszcza też zastosowanie innej bazy: w pierwszym wody po gotowaniu jęczmienia lub wódki różanej, melisowej, buraczanej lub innej; w drugim zamiast wódki anyżowej należy zastosować wino i dodatek „wódki różanej, albo konwaliowej w wodzie przepalanej”" czyli wody aromatycznej. Tego rodzaju rozbieżności występowały nie tylko w poradnikach, ale też profesjonalnych podręcznikach i dyspensatoriach przeznaczonych przeważnie dla lekarzy i aptekarzy. Wątpliwości nastręczać może już samo przygotowanie wódki anyżowej, która była podstawą stosunkowo dużej liczby recept. Wydany w 1605 roku Grundliches und vielbewehrtes Destillier und Arzney Buch autorstwa Conrada Khunratha podaje dwa sposoby uzyskania „aqua anisi”" w retorcie zalanego wodą anyżu, drugi nie przewiduje destylacji, ale kilkudniowe macerowanie anyżu w alkoholu („rectificierten Spiritum vini”), który ma przejąć jego smak, zapach i właściwości.

Ważną kwestią, której nie należy pomijać, jest także zauważalna tendencja do mnożenia dodatkowych składników ekstraktu. Nieraz zdarza się, że specyfik, który wydaje się łatwy do identyfikacji już na podstawie samej nazwy zawiera w istocie sporą ilość dodatkowych substancji. Wzmiankowana już wódka cynamonowa oprócz pół funta cynamonu (1 funt to ok. $405 \mathrm{~g}$ ) zawierała także trzy garści anyżu (szacunkowo po $20 \mathrm{~g})^{86}$. W skrajnym przypadku surowiec, od którego nazwę wziął lek, może występować w zdecydowanej mniejszości, jak np. w przypadku recepty na wódkę melisową w jednym z rękopiśmiennych poradników, gdzie oprócz melisy wymienia się jeszcze występujące w tych samych ilościach

${ }^{84}$ Ibidem, s. 627. Warto zwrócić uwagę, że w publikacji z 1789 r. (pierwsze wydanie 1715 r.) nadal pojawia się określenie „wódka” w znaczeniu wody aromatycznej, dla jednoznaczności przekazu dodano jednak informację „w wodzie przepalaney” dla odróżnienia od wódek będących „przepalanym”, czyli destylowanym roztworem alkoholu.

${ }^{85}$ C. Khunrath, Grundliches und vielbewehrtes Destillier und Arzney Buch, Hamburg 1605 , s. 300.

86 System miar staropolskich zob.: J. Szymański, Nauki pomocnicze historii, Warszawa 2004, s. 170-172. 
cztery inne składniki ${ }^{87}$. Melisa stanowiła więc jedynie $1 / 5$ składu surowcowego, co w żaden sposób nie daje się wywnioskować na podstawie samej tylko nazwy. Wydaje się, że przyjęte dziś nazwy stosowane do określania np. nalewek alkoholowych (np. cytrynowa, pigwowa, wiśniowa), oznaczające główny składnik wiodący, bardzo często nie pokrywają się z recepturami nowożytnymi. Duża część wódek leczniczych mających w nazwie substancję roślinną w istocie składa się z bardzo wielu substratów, wśród których wymieniony w nazwie wcale nie musiał być dominujący. Przyjęte do tej pory metody interpretacji efektów leczniczych wyciągów roślinnych oparte na analizie właściwości fitochemicznych rośliny wymienionej w nazwie należy zatem traktować z dużą ostrożnością.

Z punktu widzenia dzisiejszej fitoterapii duże znaczenie ma wykorzystanie konkretnego fragmentu substancji roślinnej z uwagi na fakt, że różne części roślin mogą mieć odmienną zawartość związków chemicznych ${ }^{88}$. Precyzyjne określenie, jaki fragment rośliny należy wykorzystać, występowało $\mathrm{w}$ dawnych receptach stosunkowo rzadko. W przypadku wybranych roślin można przyjąć za najbardziej prawdopodobne wykorzystywanie do produkcji leków części zwyczajowo używanych w ziołolecznictwie. Jest to jednak przybliżenie obarczone pewnym ryzykiem, gdyż w niektórych staropolskich receptach podających precyzyjny opis składu zaleca się wykorzystanie surowców, których dzisiejsza fitoterapia nie stosuje (np. kwiatów melisy, korzonków macierzanki).

Jak już wspomniano, nowożytne receptariusze i poradniki rzadko zawierały dokładny opis procesu produkcyjnego, wyjaśniający wszystkie potencjalne niejasności. Pojawiające się recepty często wyszczególniają jedynie składniki lub używają terminologii, która nastręcza poważnych wątpliwości co do charakteru i ostatecznego składu preparatu. Niejednoznaczne nazewnictwo, nieujednolicone procedury produkcji, brak precyzyjnej diagnozy i wielość stosowanych metod leczenia tych samych dolegliwości w pewnym

${ }^{87}$ Biblioteka Zakładu Narodowego im. Ossolińskich we Wrocławiu, rkps 811/I: Przepisy medyczne i gospodarskie, s. 190.

${ }^{88} \mathrm{Na}$ przykład związki aktywne chmielu zlokalizowane są w gruczołach chmielu (lupulina) występujących w szyszkach chmielowych, a nieobecnych w innych fragmentach rośliny: Encyklopedia zielarstwa i ziotolecznictwa, red. H. Strzelecka i J. Kowalski, Warszawa 2000, s. 87. 
stopniu wiązały się ze specyfiką dominującej wówczas doktryny humoralnej. W efekcie trudno o jednoznaczne opisanie i scharakteryzowanie stosowanych w epoce nowożytnej leków, w tym ziołowych ekstraktów leczniczych. O ile w źródłach nie występuje precyzyjny opis preparatu łącznie z dokładnym określeniem procesu produkcji, pozostaje jedynie możliwość przypuszczeń co do jego właściwości terapeutycznych. Mając na uwadze charakterystykę źródeł nowożytnych i sposób opisu wykorzystywanych leków, są to przypuszczenia częstokroć obarczone niemałym ryzykiem błędu.

W publikacjach poświęconych tematyce dawnej zdrowotności często można natknąć się na próby interpretowania potencjalnych działań terapeutycznych leków (w tym wódek) tylko na podstawie analizy wykorzystanych w nich składników. Tymczasem proces produkcji i stosowane w epoce nowożytnej metody obróbki (np. wyprażanie w wysokiej temperaturze, zalewanie roztworem kwasu itp.) bardzo często wpływały na zmianę składu chemicznego finalnego preparatu. Powodowało to niejednokrotnie zniwelowanie efektu terapeutycznego, który miałyby składniki przed procesem produkcji, a niejednokrotnie wiązało się też z powstaniem innych substancji chemicznych, które mogły nie być obojętne dla organizmu. Tym samym należy przyjąć, że próby wyrokowania o potencjalnym działaniu leków, zwłaszcza złożonych preparatów, powinny być poprzedzone wnikliwą analizą obejmującą sprawdzenie sposobu wykonania medykamentu. Podobnie w przypadku wódek leczniczych, większość publikacji poświęconych dawnym metodom leczenia zakłada, że wymienione w recepcie składniki zostały zalane roztworem alkoholowo-wodnym, co wiązałoby się z przechodzeniem większości substancji aktywnych do wyciągu (wódki leczniczej). Tymczasem, jak już wykazano, często „wódki” nie zawierały alkoholu i były wykonane na podstawie wodnych maceratów. Z punktu widzenia obecności związków biologicznie aktywnych, a co za tym idzie potencjalnej skuteczności leku, zawartość alkoholu w przygotowywanym maceracie ma niemałe znaczenie, gdyż część związków bardzo trudno rozpuszczalnych $\mathrm{w}$ wodzie będzie dobrze rozpuszczać się w roztworze wodno-alkoholowym ${ }^{89}$. Ponadto w przypadku leczniczych ekstraktów ziołowych, na

89 Przykładem może tu być kwercetyna, związek szeroko rozpowszechniony w świecie roślinnym, wykorzystywany we współczesnej fitoterapii ze względu m.in. na działanie 
podstawie analizy dawnych receptariuszy i poradników, należy stwierdzić, że duża część „wódek”, niezależnie od użytego rozpuszczalnika i procesu wstępnego przygotowania, była w końcowym etapie destylowana. Oznacza to, że nie można wyciągać wiążących wniosków odnośnie do potencjalnego efektu terapeutycznego tylko na podstawie składu surowcowego preparatu. Wynika to ze specyfiki procesu destylacji („przepalania”), czyli odparowywania, a następnie skroplenia lotnych substancji zawartych w nastawie. Tym samym uzyskany terapeutyk nie będzie zawierał związków nielotnych, które wchodziły w skład wykorzystanych surowców. Nie wszystkie lecznicze ekstrakty ziołowe (w tym nie wszystkie „wódki”) były jednak poddawane destylacji, nie można więc reguły tej stosować bezwzględnie.

$\mathrm{Na}$ obecnym etapie badań trudno jednoznacznie stwierdzić, jaki odsetek spośród leczniczych ekstraktów ziołowych miał w sobie alkohol. W stosunku do „gorzałek” uzasadnione jest przyjęcie ogólnego założenia, że są to maceraty bazujące na destylatach alkoholowych (uprzednio „przepalonych”), choć nie można odrzucić możliwości występowania wyjątków od tej zasady, np. ze względu na dopuszczane przez medycynę nowożytną zmiany w składzie leku i alternatywne metody jego wykonania. Nierozwikłane pozostają za to wątpliwości co do zawartości alkoholu w lekach występujących w źródłach pod nazwą „wódka”. Wydaje się, że w XVIII wieku większa część „wódek” zawierała alkohol, aby jednak udokumentować spekulacje rzetelnymi badaniami, należałoby prześledzić opis wykonywania reprezentatywnej grupy preparatów występujących w receptariuszach, dyspensatoriach, poradnikach i podręcznikach medycznych pod kątem procesu produkcyjnego i użytych surowców (w kontekście zawartości alkoholu). Zadanie to wymaga odrębnych, szeroko zakrojonych badań, których wynik na obecnym etapie trudno przewidzieć, gdyż duża część recept (jak już wielokrotnie wspominano) nie zawiera szczegółowego opisu składu i procesu produkcji. Należy przy tym podkreślić, że w przypadku preparatów, które w końcowym etapie produkcji podlegały destylacji, fakt użycia wody lub roztworu wodno-alkoholowego jako rozpuszczalnika pozostawał drugorzędny, gdyż substancje lotne, które jako jedyne będą obecne w gotowym

przeciwutleniające i uszczelniające naczynia krwionośne: [https://pubchem.ncbi.nlm.nih. gov/compound/quercetin\#section=Top, dostęp: 05.06 .2017$]$. 
leku, w przytłaczającej większości przypadków rozpuszczają się zarówno w wodzie, jak i alkoholu.

Podsumowując, trzeba stwierdzić, że badając wykorzystanie lecznicze ekstraktów ziołowych i ich potencjalną skuteczność, oprócz analizy składu niezmiernie ważne będą szczegóły procesu produkcyjnego, takie jak czas maceracji, wykorzystany rozpuszczalnik, użycie wysokiej temperatury, działanie silnie aktywnymi substancjami chemicznymi itp. Z punktu widzenia zawartości związków biologicznie czynnych kluczowe jest też ustalenie, czy preparat został poddany destylacji - w takiej sytuacji, niezależnie od składu wykorzystanych surowców, jedynie substancje lotne z parą wodną będą obecne w leku. Bardzo istotne jest też wskazanie pełnego składu specyfiku - poleganie jedynie na substancji występującej w nazwie może okazać się bardzo mylące. Nie bez znaczenia pozostaje też fakt wykorzystywania w nowożytnym lecznictwie różnych części roślin, których dzisiejsza fitoterapia już nie stosuje. Wydaje się, że w większości wypadków można założyć, że chodzi o fragmenty roślin zwyczajowo użytkowanych leczniczo, pozostaje to jednak tylko domniemanie.

Biorąc pod uwagę wszystkie przytoczone trudności interpretacyjne oraz mnogość niewiadomych, z którymi trzeba zmierzyć się podczas próby określenia właściwości leczniczych ekstraktów ziołowych, uzasadnione wydaje się twierdzenie, że „wódka wódce nierówna”. W praktyce można je odnieść z powodzeniem do niemal wszystkich leków stosowanych w medycynie nowożytnej, gdyż prawie zawsze pojawiają się wątpliwości co do składu, procesu produkcji czy sposobu podawania. Wyrokowanie o skuteczności terapeutycznej dawnych leków powinno być każdorazowo poprzedzone bardzo wnikliwym badaniem ich składu i metod wytwarzania. 